\title{
CORRIGENDUM
}

\section{On the occurrence of sei whales, Balaenoptera borealis, in the south-western Atlantic - CORRIGENDUM}

MIGUEL IÑÍGUEZ, JUAN F. MASELLO, CÉSAR GRIBAUDO, DÉBORA ARCUCCI, FLORENCIA KROHLING AND JIMENA BELGRANO

doi:10.1017/S1755267210000576, Published by Cambridge University Press, 29 June 2010

The authors regret that Figure $1 \mathrm{~B}$ of this article (Iñíguez et al., 2010) was incorrectly supplied. The correct version of the figure part is provided below.

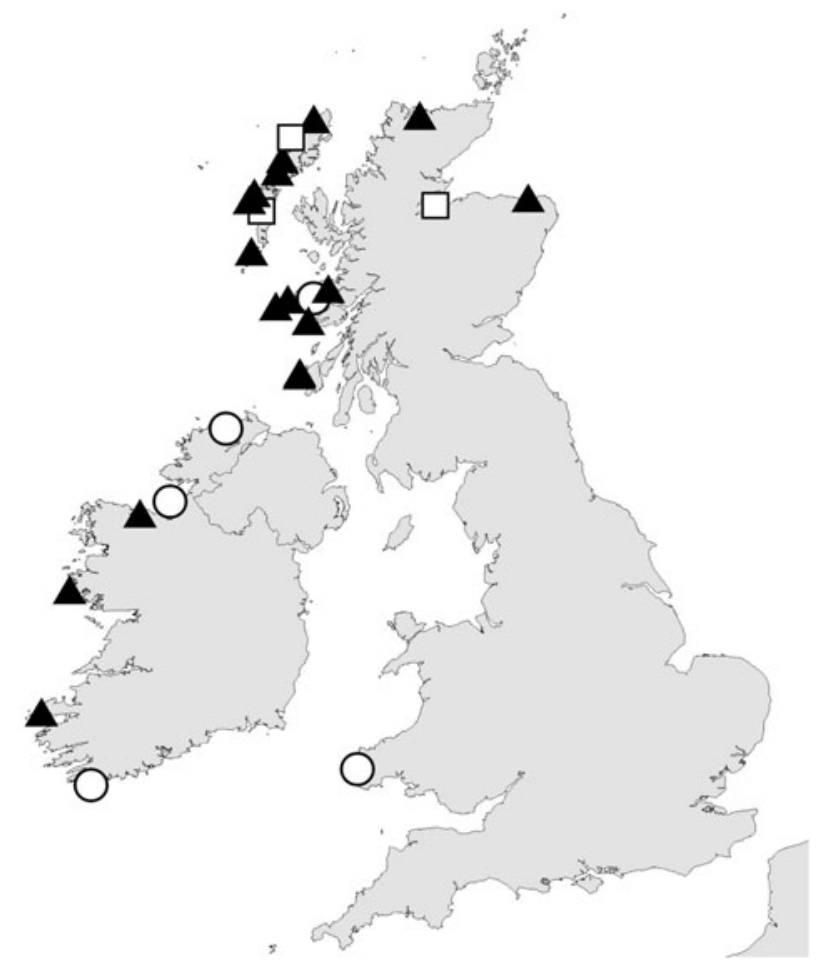

REFERENCE

Miguel Iñiguez, Juan F. Masello, César Gribaudo, Débora Arcucci, Florencia Krohling and Jimena Belgrano (2010) On the occurrence of sei whales, Balaenoptera borealis, in the south-western Atlantic. Marine Biodiversity Records, 3, e68 doi:10.1017/S1755267210000576 